\title{
[3,3]-Sigmatropic Rearrangements of Fluorinated Allyl (Thio)cyanates - A Tool for the Synthesis of Fluorinated (Thio)ureas
}

\author{
Daniel C. Ramb, Lisa Kost, and Günter Haufe* \\ Dedicated to Professor Klaus Schulze on the occasion of his 80th birthday
}

\begin{abstract}
The first (thio)cyanate to iso(thio)cyanate rearrangements based on 2-fluoroallylic alcohols are presented. Long-chain 2-fluoroallylic alcohols were converted to corresponding $N$-unsubstituted carbamates by treatment with trichloroacetyl isocyanate. Dehydration using trifluoroacetic anhydride in the presence of triethylamine formed intermediate allylic cyanates, which immediately underwent sigmatropic rearrangement to fluorinated allyl isocyanates. Without isolation the latter delivered fluorinated ureas by addition of amines. The thiocyanate to isothiocyanate rearrangements started from the same fluorinated allylic alcohols, which were first converted to mesylates. Heating in THF with potassium thiocyanate led to fluorinated allyl isothiocyanates, via $[3,3]$-sigmatropic rearrangement of intermediate allyl thiocyanates. The formed products were further reacted with amines to fluorinated thioureas.
\end{abstract}

Keywords: Cyanates · 2-Fluorallylic alcohols · Fluorinated ureas and thioureas · Isocyanates · Isothiocyanates $\cdot[3,3]$-Sigmatropic rearrangements $\cdot$ Thiocyanates

\section{Introduction}

The thermal rearrangement of allyl thiocyanates to allyl isothiocyanates (mustard oils) is a very well-known method ${ }^{[1]}$ for the preparation of key intermediates, for the synthesis of $e$.g. thioureas and thiocarbamates for agrochemical and pharmaceutical purposes ${ }^{[2]}$ and for organocatalytic applications due to their high hydrogen bonding activity. ${ }^{[3]}$ As early as 1885 Billeter and independently Gerlich discovered the reaction and in 1925 Billeter proposed a cyclic transition state for the rearrangement despite not having any supporting evidence. ${ }^{[4]}$ Later, the concept was supported by experimental evidence ${ }^{[5]}$ and more recently the reaction was confirmed by further experimental and theoretical investigations to proceed as a [3,3]-sigmatropic rearrangement. ${ }^{[6]}$ In general the reaction is irreversible because isothiocyanates are thermodynamically more stable, but under particular circumstances,

${ }^{*}$ Correspondence: Prof. Dr. G. Haufe Organisch-Chemisches Institut Münster Westfälische Wilhelms-Universität Münster Corrensstraße 40, 48149 Münster, Germany Tel.: +492518333281

E-Mail: haufe@uni-muenster.de isothiocyanates can be rearranged to thiocyanates when the formed carbon skeleton becomes more stable. ${ }^{[7]}$

In contrast, the allyl cyanate to allyl isocyanate rearrangement became available to organic chemists much later due to the lack of pathways to synthesize allyl cyanates and to very easy formation of cyclic trimers, the trialkyl cyanurates. ${ }^{[8]}$ Simple allyl cyanates are about $5 \mathrm{kcal} / \mathrm{mol}$ less stable than the sulfur analogues ${ }^{[6 b]}$ and practically unisolable ${ }^{[9]}$ due to the very low activation barrier of isomerization to the allyl isocyanates of $15-20 \mathrm{kcal} / \mathrm{mol}^{\left[{ }^{[6,9]}\right.}$ The evolution, development and synthetic applications of this [3,3]-sigmatropic rearrangement have been reviewed a couple of years ago ${ }^{[8 b, 10]}$ and the mechanism was confirmed again by recent quantum chemical calculations. ${ }^{6 \mathrm{~b}]}$ Like the isothiocyanates, also the cyanates play an important role as intermediates for the synthesis of biologically active compounds and particularly as monomers for polymerization reactions..$^{[1]}$

In recent years, [3,3]-sigmatropic rearrangements of fluorine-containing allylic systems have become a powerful tool to generate new fluorinated molecules by carbon-carbon or carbon-heteroatom bond formation. By way of example, Claisen rearrangements of polyfluorinated allylvinyl ethers, ${ }^{[12]}$ Johnson-Claisen rearrangements of terminal 1,1-difluoroallylic alcohols, ${ }^{[13]}$ and Ireland-Claisen rearrangements of 1,1-difluorinated allyl esters have been published. ${ }^{[14]}$ Fewer examples were known for [3,3]-sigmatropic rearrangements involving monofluorinated double bonds. ${ }^{[15]}$ In systematic studies we have shown that a variety of [3,3]-sigmatropic rearrangements such as the Johnson-Claisen, the Ireland-Claisen, the ester enolate, the Eschenmoser and the Overman rearrangements based on 2-fluoroallylic alcohols are useful methods to synthesize fluorinated, $\gamma, \delta$-unsaturated carboxylic acids, esters, amino acids, carboxylic acid amides, or allylamines, respectively. ${ }^{[16]}$ Here we disclose our first results on [3,3]-sigmatropic rearrangements of fluorinated allyl (thio) cyanates.

\section{Results and Discussion}

The starting material for the rearrangement precursors, the 2-fluoroallylic alcohols $\mathbf{1}$ and $\mathbf{2}$, were synthesized according to our well-known three-step procedure of bromofluorination of 1-alkenes, $\mathrm{HBr}$ elimination from the formed 1-bromo2-fluoroalkanes and subsequent allylic oxidation of the vinylfluorides with selenium dioxide to give the target compounds in $28-35 \%$ overall yield (Scheme 1). ${ }^{[17]}$ The non-fluorinated allylic alcohol 3 was synthesized by allylic oxidation of hexadec1-ene. 


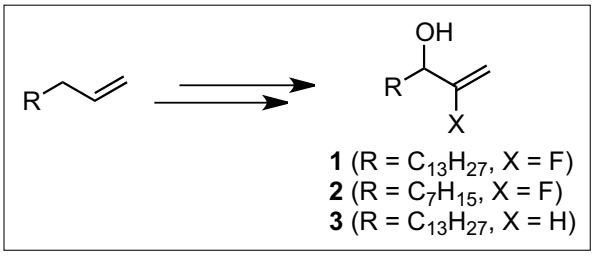

Scheme 1. Synthesis of 2-fluoroallylic alcohols 1-3.

\subsection{Cyanate to Isocyanate Rearrangement}

In one of the early reports on cyanate to isocyanate rearrangement, Overman used cyanogen chloride to synthesize cyanates from allylic alcohols. ${ }^{[9 b]}$ The major drawback of cyanogen chloride is the high toxicity and difficult handling of the gas. Therefore, we first tried to replace cyanogen chloride with the solid cyanogen bromide. Unfortunately all attempts with different bases or solvents failed to convert 1 to the target cyanate or the rearranged isocyanate (Scheme 2).

Also all attempts with the fluorine-free allylic alcohol 3 failed. Thus, the lower reactivity of the reagent $\mathrm{BrCN}$ and not the decreased nucleophilicity of the allylic alcohol function due to the electron withdrawing effect of the adjacent fluorine atom seems to be the reason for the failure. Therefore, we next investigated Ishikawa's method of dehydration of allyl carbamates leading to cyanates, which do rearrange immediately. ${ }^{[18]}$

Similarly to a literature procedure, ${ }^{[19]}$ the allylic alcohols 1-3 were first transformed to the target carbamates 7-9 via the mixed imides 4-6 in good to excellent yields (Scheme 3, Table 1).

Next we optimized the reaction conditions for the dehydration reaction using $\mathbf{8}$ as model compound (Scheme 4). The reaction was controlled by TLC. IR spectra of the crude reaction mixture showed the typical peak of the isocyanate moiety at $2259 \mathrm{~cm}^{-1}$. Attempts to isolate the isocyanate or the amine after aqueous workup failed (Table 2).

Thus the intermediate isocyanates were directly treated with aniline or piperidine forming the corresponding ureas in moderate to good yield over three steps (Scheme 5, Table 3).

The rearrangement to the isocyanate occurred via a six-membered transition state and hence gave the trans-configured ureas exclusively. This configuration was confirmed by the typical large ${ }^{3} J_{\mathrm{H}, \mathrm{F}}=36 \mathrm{~Hz}$ coupling constant. The moderate yields for aniline adducts are due to difficult isolation. A diisocyanate addition product was never observed. No significant influence of the fluorine atom was observed as yet but further investigations with broader variety of allylic alcohols and amines are in progress.

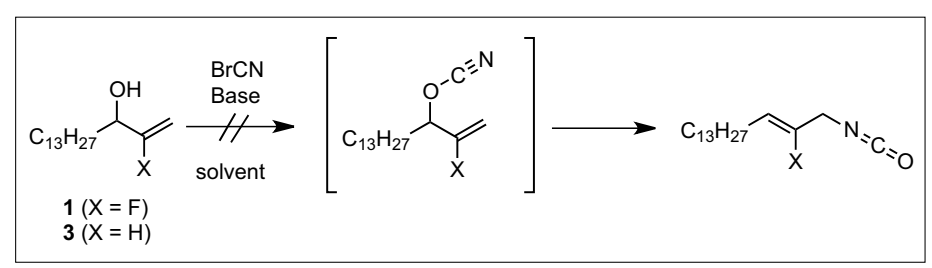

Scheme 2.

Unsuccessful synthesis of isocyanates using cyanogen bromide.

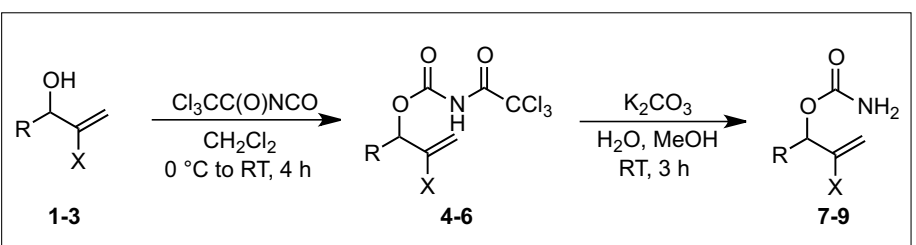

Scheme 3. Synthesis of allylic carbamates 7-9.

Table 1. Results of the synthesis of allylic carbamates 7-9.

\begin{tabular}{|c|c|c|c|c|}
\hline Substrates & $\mathrm{R}$ & $\mathrm{X}$ & Products [yield] $^{\mathrm{a}}$ & Products [yield] $^{\mathrm{a}}$ \\
\hline $\mathbf{1}$ & $\mathrm{C}_{13} \mathrm{H}_{27}$ & $\mathrm{~F}$ & $\mathbf{4}[98 \%]$ & $\mathbf{7}[99 \%]$ \\
\hline $\mathbf{2}$ & $\mathrm{C}_{13} \mathrm{H}_{27}$ & $\mathrm{~F}$ & $\mathbf{5}[98 \%]$ & $\mathbf{8}[91 \%]$ \\
\hline $\mathbf{3}$ & $\mathrm{C}_{13} \mathrm{H}_{27}$ & $\mathrm{H}$ & $\mathbf{6}[97 \%]$ & $\mathbf{9}[65 \%]$ \\
\hline
\end{tabular}

asolated yields

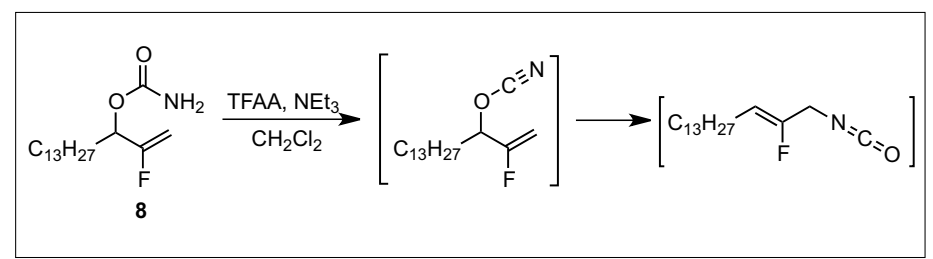

Scheme 4. Reaction pathway forming isocyanates by dehydration reaction of $\mathbf{8}$ and subsequent rearrangement.

Table 2. Conditions for the dehydration reaction of $\mathbf{8}$.

\begin{tabular}{|c|c|c|c|c|}
\hline Entry & Equiv NEt & Equiv TFAA & Temperature & Result \\
\hline 1 & 1 & 3 & $-78^{\circ} \mathrm{C}$ to r.t. & no reaction \\
\hline 2 & 1 & 3 & $0^{\circ} \mathrm{C}$ to r.t. & incomplete conversion \\
\hline 3 & 3 & 3 & $0^{\circ} \mathrm{C}$ to r.t. & full conversion \\
\hline
\end{tabular}

Scheme 5. Strategy for the synthesis of fluorinated and nonfluorinated ureas 10-15.

Table 3. Results for the synthesis of the fluorinated and non-fluorinated ureas 10-15.

$\begin{array}{cccccc}\text { Entry } & \mathrm{R} & \mathrm{X} & \mathrm{Nu} & \text { Product } & \text { Yield [\%] } \\ 1 & \mathrm{C}_{13} \mathrm{H}_{27} & \mathrm{~F} & \text { Piperidine } & \mathbf{1 0} & 79 \\ 2 & \mathrm{C}_{13} \mathrm{H}_{27} & \mathrm{~F} & \text { Aniline } & \mathbf{1 1} & 30 \\ 3 & \mathrm{C}_{13} \mathrm{H}_{27} & \mathrm{H} & \text { Piperidine } & \mathbf{1 2} & 78 \\ 4 & \mathrm{C}_{13} \mathrm{H}_{27} & \mathrm{H} & \text { Aniline } & \mathbf{1 3} & 73 \\ 5 & \mathrm{C}_{7} \mathrm{H}_{15} & \mathrm{~F} & \text { Piperidine } & \mathbf{1 4} & 76 \\ 6 & \mathrm{C}_{7} \mathrm{H}_{15} & \mathrm{~F} & \text { Aniline } & \mathbf{1 5} & 35\end{array}$




\subsection{Thiocyanate to Isothiocyanate Rearrangement}

The thiocyanate to isothiocyanate rearrangement in principle should be accomplished by initial transformation of the $\mathrm{OH}$-group in the 3-position to a leaving group and its subsequent nucleophilic substitution with the -SCN anion to a thiocyanate followed by [3,3]-sigmatropic rearrangement. However the particular allylic system and the ambident reactivity of the thiocyanate anion create the dilemma of different possible reaction pathways:

a) $\mathrm{S}_{N} 2$ reaction with nucleophilic attack of the sulfur atom of the ${ }^{-} \mathrm{SCN}$ anion on the most electrophilic carbon atom forming an allylic thiocyanate $\mathbf{I}$ and subsequent rearrangement to the primary isothiocyanate II (Scheme 6a).

b) $\mathrm{S}_{\mathrm{N}} 2$ ' reaction with a nucleophilic attack of the thiocyanate's sulfur atom at the terminal position. The resulting primary thiocyanate could then rearrange to the secondary isothiocyanate (Scheme 6b).

c) Furthermore, due to the ambident reactivity of the SCN anion a nucleophilic attack of the thiocyanate anion with the nitrogen atom is also possible. Calculations by Mayr et al. have shown a more nucleophilic character of the sulfur atom but an attack of the nitrogen atom cannnot be excluded. ${ }^{[20 a, b]}$ A competitive $\mathrm{S}_{\mathrm{N}} 2^{\prime}$ and $\mathrm{S}_{\mathrm{N}} 2$ reaction might result in two regioisomeric isothiocyanates IV and II (Scheme 6c).

Consequently, we synthesized the mesylates 16 and 17, which were stable enough to be isolated and characterized. For the substitution reaction and subsequent rearrangement we tested different reaction conditions. Best results for the formation of isothiocyanate 19 were achieved by heating of mesylate 17 with potassium thiocyanate in dry THF at $60{ }^{\circ} \mathrm{C}$ for $26 \mathrm{~h}$ in a sealed tube (Scheme 7). Using the tosylate, other solvents, temperatures or microwave irradiation resulted in worse product ratios. For instance, treating the tosylate under the same reaction conditions led to additional fluorinated products. Under the optimal reaction conditions one major product and three minor products were formed. Based on our knowledge on similar vinyl fluorides we assign the doublet of triplet at $-118 \mathrm{ppm}$ in the ${ }^{19} \mathrm{~F}$ NMR spectrum (Fig. 1) to compound $\mathbf{1 9}$ with a fluorine atom attached to an 1,2-disubstituted double bond, while the doublet of doublet of doublet at -109 ppm belongs to a vinylic fluorine in 2-position at the terminal double bond (compound $\mathbf{2 1}$ ). Analogous results were obtained for the rearrangement of the higher homologue 16. A similar substitution pattern with a doublet of doublet of doublet at $\delta=-107$ ppm in the ${ }^{19} \mathrm{~F}$ NMR spectrum and a doublet of doublet at $\delta=4.64 \mathrm{ppm}$ and doublet of doublet at $\delta=4.87 \mathrm{ppm}$ in the ${ }^{1} \mathrm{H}$ NMR

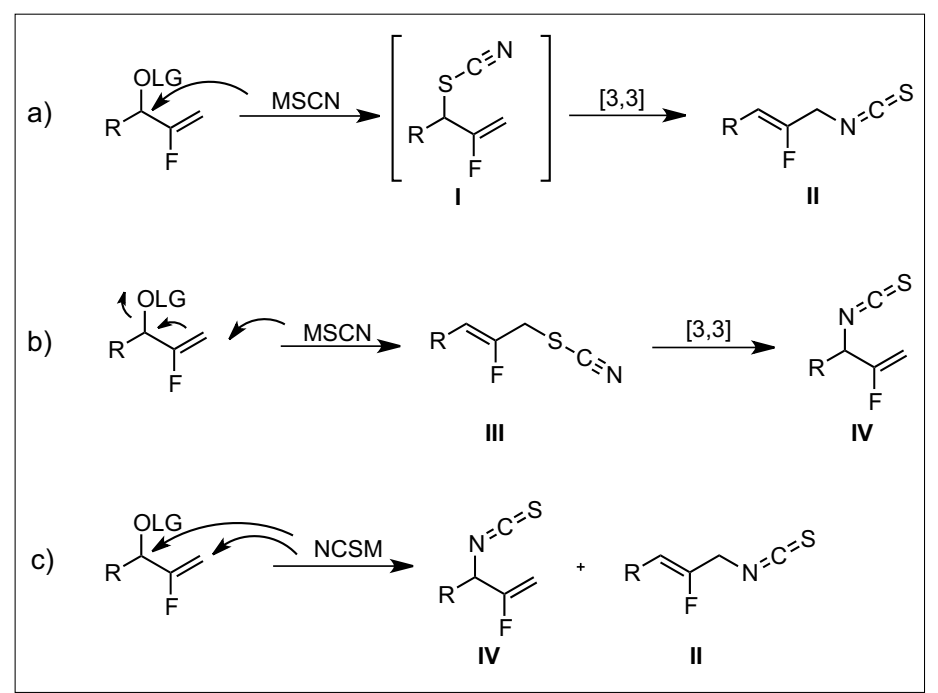

Scheme 6. Possible reaction pathways for nucelophilic substitution with the ambident thiocyanate anion on the particular allylic system.

spectrum are assigned to the thiocyanate 23, which is supported by the weak band at $2157 \mathrm{~cm}^{-1}$ in the IR spectrum of the crude product mixture. Furthermore, the quartet at $\delta=-111 \mathrm{ppm}$ in the ${ }^{19} \mathrm{~F}$ NMR spectrum and the doublet of triplet at $\delta=5.32 \mathrm{ppm}$ in the ${ }^{1} \mathrm{H}$ NMR spectrum suggest the presence of compound $\mathbf{2 5}$ in the crude product mixture.

The regioisomers $18 / 19$ and $20 / 21$ were formed in ratios of $82-83$ and $6-7 \%$ $\left({ }^{19} \mathrm{~F}\right.$ NMR). These compounds could not be separated from each other and from the two not fully characterized products $\mathbf{2 2 / 2 3}$ and $\mathbf{2 4 / 2 5}$, respectively, by column chromatography.

In addition to the weak band of allylic thiocyanate 23 at $2157 \mathrm{~cm}^{-1}$, the IR spectrum contains the intense broad band for isothiocyanates at $2054 \mathrm{~cm}^{-1}$. In order to find out whether the thiocyanate is formed at the beginning of the reaction, we ana-

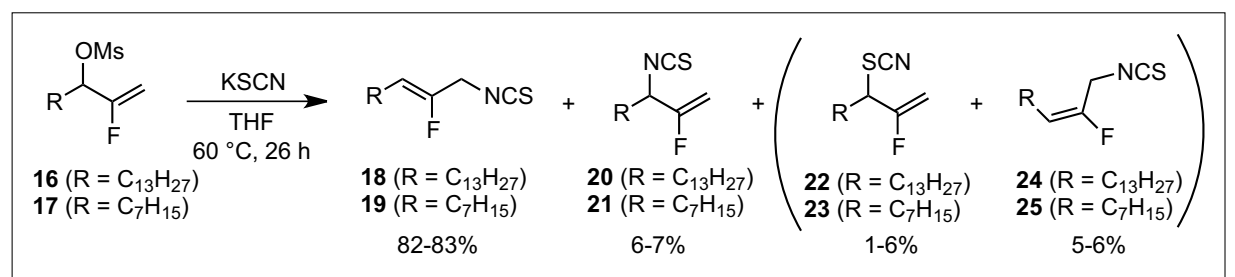

Scheme 7 . Synthesis of isothiocyanates $\mathbf{1 8}, \mathbf{1 9}$ and side products.

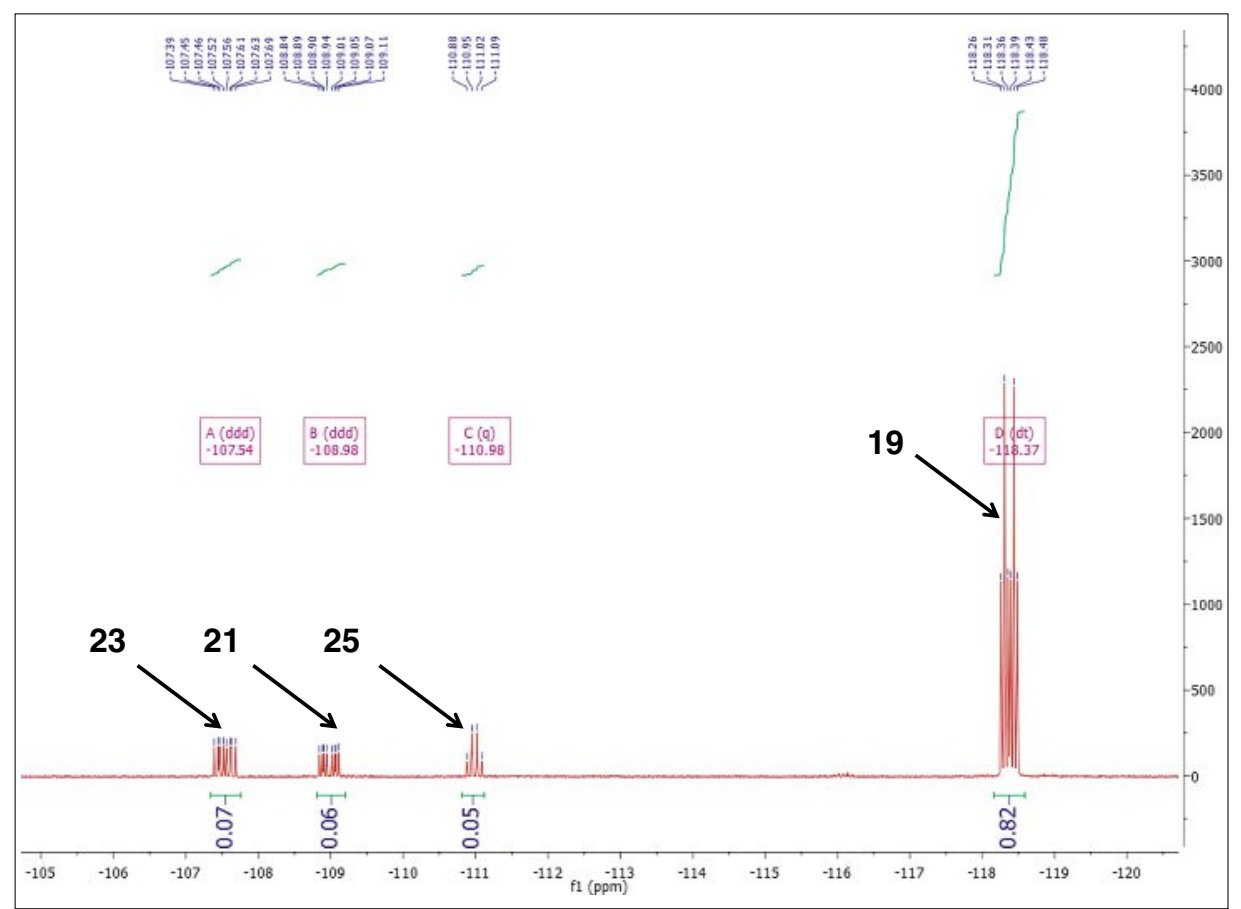

Fig. $1 .{ }^{19} \mathrm{~F}$ NMR spectrum of the crude product mixture after heating of $\mathbf{1 7}$ with KSCN in THF. 
lyzed aliquots of the crude product mixture after short reaction times and found the typical thiocyanate absorption at 2157 $\mathrm{cm}^{-1}$ which decreased due to the rearrangement to the thermodynamically more stable isothiocyanate. Thus pathway a) seems to be preferred. A primary thiocyanate III (pathway b) was not observed at any time of the reaction. Parallel pathway c), the nucleophilic attack of the nitrogen of the ambident anion SCN, is not excluded, though a different ratio of products 19 and 25 might be expected. Moreover, according to calculations on $\mathrm{S}_{\mathrm{N}}$ 2-type reactions, ${ }^{[20]}$ the sulfur atom has the lower intrinsic barrier in the ambident thiocyanate anion and hence this attack is favored. In addition, the attack on the most electrophilic carbon atom forming a thiocyanate of type $\mathbf{I}$ results in a lower energy uptake for reorganizing regarding atomic position and electronic configuration, which both would support pathway a) initiated by a nucleophilic attack of the sulfur in a $\mathrm{S}_{\mathrm{N}} 2$ reaction. Regarding the spectroscopic data for both isothiocyanates $\mathbf{1 8}$ and $\mathbf{1 9}$ the trans-configuration of the double bonds is indicated by the big coupling constant $\left({ }^{3} J_{\mathrm{H}, \mathrm{F}}=35 \mathrm{ppm}\right)$, which is an additional argument for a [3,3]-sigmatropic rearrangement.

The structure of a type-III-thiocyanate (compound 28) and a type-IV-isothiocyanate (compound 29) was independently confirmed by fluorine NMR data of products of an 'inverse' thiocyanate rearrangement. Starting from the diastereomeric fluorinated allyl alcohols 26 (2:1, synthesized from the corresponding $\alpha$-fluoro$\alpha, \beta$-unsaturated esters $\left.{ }^{[21]}\right)$, the mesylates 27 were prepared and reacted with potassium thiocyanate in acetonitrile at $60{ }^{\circ} \mathrm{C}$ yielding a $2: 1$ mixture of isomers $28(2: 1)$ and 29. Further heating in toluene for $4 \mathrm{~h}$ completed the rearrangement of $\mathbf{2 8}$ to $\mathbf{2 9}$ (Scheme 8). The isothiocyanate 29 was formed as the sole product showing a doublet of doublet of doublet at $-109 \mathrm{ppm}$ with the same pattern as in compounds 20/21. Signals similar to those of compounds $\mathbf{2 8}$ were not found in the crude product of the reactions of $\mathbf{1 6}$ or $\mathbf{1 7}$ with $\mathrm{KSCN}$ (see above).

Next the above prepared mixtures of rearrangement products 18/19 (contaminated with the minor side products) were treated with aniline and piperidine forming fluorinated thioureas $\mathbf{3 0 / 3 1}$ and $\mathbf{3 2 / 3 3}$ in $40-54 \%$ isolated yields by microwave irradiation for $1 \mathrm{~h}$ (Scheme 9, Table 4). Products formed from the minor impurities were not detected in the final products after purification.

Unfortunately, a potential influence of the fluorine atom on the rearrangement rate could not be investigated because the fluorine-free analogue of mesylate $\mathbf{1 7}$ (or

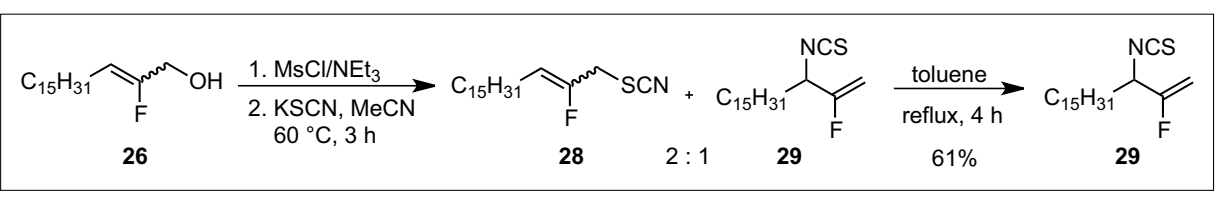

Scheme 8. Inverse thiocyanate rearrangement.

\begin{tabular}{|c|c|c|}
\hline$\overbrace{F} N C S$ & $\begin{array}{c}\stackrel{\text { Nucleophile }}{\longrightarrow} 100^{\circ} \mathrm{C} \\
\mathrm{MW}, 1 \mathrm{~h}\end{array}$ & $\vec{F}$ \\
\hline $\begin{array}{l}18\left(\mathrm{R}=\mathrm{C}_{13} \mathrm{H}_{27}\right) \\
19\left(\mathrm{R}=\mathrm{C}_{7} \mathrm{H}_{15}\right)\end{array}$ & & $\begin{array}{l}\text { 30/31 }\left(\mathrm{R}=\mathrm{C}_{13} \mathrm{H}_{27}\right) \\
\mathbf{3 2 / 3 3}\left(\mathrm{R}=\mathrm{C}_{7} \mathrm{H}_{15}\right)\end{array}$ \\
\hline
\end{tabular}

Scheme 9. Nucleophilic addition of 18 and 19 with different nucleophiles.

the corresponding tosylate) could not be prepared due to elimination reaction. The instability of allylic mesylates has already been reported. ${ }^{[22]}$ Surprisingly, the fluorine stabilizes this leaving group in allylic position and the resulting mesylates and tosylates could be stored for weeks.

\section{Conclusion}

In conclusion, [3,3]-sigmatropic rearrangements of secondary allyl (thio)cyanates delivered different fluorinated and non-fluorinated primary allyl iso(thio)cyanates, which were further converted to the corresponding (thio)ureas. We achieved a selective allyl cyanate to allyl isocyanate rearrangement on fluorinated compounds for the first time. The mechanism of formation of allyl isothiocyanates, however, is not fully approved yet, but we suspect that a [3,3]-sigmatropic rearrangement took place. Additional investigations on the electronic structure of these fluorinated allylic systems will be necessary. Furthermore, we were able to rearrange a fluorine-containing primary allyl thiocyanate to the secondary allyl isothiocyanate by heating. Finally microwave irradiation of the fluorinated primary allyl isothiocyanates with amines produced corresponding fluorinated thioureas. We intend to investigate potential applications of the prepared fluorinated (thio)ureas as organocatalysts and to study the effect of the fluorine atom on the selectivity.

\begin{tabular}{|c|c|c|c|c|}
\hline Entry & $\mathrm{R}$ & $\mathrm{Nu}$ & Product & Yield [\%] \\
\hline 1 & $\mathrm{C}_{13} \mathrm{H}_{27}$ & Piperidine & $\mathbf{3 0}$ & 52 \\
\hline 2 & $\mathrm{C}_{13} \mathrm{H}_{27}$ & Aniline & $\mathbf{3 1}$ & 46 \\
\hline 3 & $\mathrm{C}_{7} \mathrm{H}_{15}$ & Piperidine & $\mathbf{3 2}$ & 54 \\
\hline 4 & $\mathrm{C}_{7} \mathrm{H}_{15}$ & Aniline & $\mathbf{3 3}$ & 40 \\
\hline
\end{tabular}

\section{Experimental Part}

All commercial reagents were used without further purification. Air-sensitive reactions were conducted in flame-dried flasks under argon atmosphere. Melting points are uncorrected. NMR spectra were recorded at $300 \mathrm{MHz}\left({ }^{1} \mathrm{H}\right)$, at $75 \mathrm{MHz}$ $\left({ }^{13} \mathrm{C}\right)$ and at $282 \mathrm{MHz}\left({ }^{19} \mathrm{~F}\right)$ and are reported in ppm downfield from TMS $\left({ }^{1} \mathrm{H}\right.$ and ${ }^{13} \mathrm{C}, \mathrm{CDCl}_{3}$ as internal standard and $\left.\mathrm{CFCl}_{3},{ }^{19} \mathrm{~F}\right)$. Signals were assigned with the help of ${ }^{1} \mathrm{H}$ NMR (GCOSY), $\left({ }^{1} \mathrm{H}\right.$ and ${ }^{13} \mathrm{C}$ ) with GHSQC and GHMBC. ESI mass spectra were recorded on a Finnigan MAT 4200S. Column chromatography (silica gel Merck 60, 0.040-0.063 mm) was used for purification. Fluorinated allylic alcohols were prepared according to ref. [17]. Carbamates were prepared according to ref. [19]. Methanesulfonyl- and toluenesulfonyl compounds were prepared following standard procedures.

\subsection{General Procedure for the Synthesis of Ureas 10-15 from Carbamates 7-9 by Dehydration, [3,3]-Sigmatropic Rearrangement and Addition of the Amine to the Intermediate Isocyanates}

Under an argon atmosphere the corresponding carbamate ( $0.2 \mathrm{mmol}, 1.0$ equiv) is dissolved in dry dichloromethane (3 $\mathrm{mL}$ ) and cooled to $0{ }^{\circ} \mathrm{C}$. Triethylamine (83 $\mu \mathrm{L}, 0.6 \mathrm{mmol}, 3.0$ equiv) and trifluoroacetic acid anhydride $(84 \mu \mathrm{L}, 0.6 \mathrm{mmol}$, 3.0 equiv freshly distilled from $\mathrm{P}_{2} \mathrm{O}_{5}$ ) are added slowly to the solution and the mixture is stirred for two more hours at $0{ }^{\circ} \mathrm{C}$. After warming to room temperature the amine ( 1.3 equiv) is added and the solution is stirred at room temperature over night. Water $(5 \mathrm{~mL})$ is added and the phases are separated. The aqueous phase is extracted with dichloromethane $(5 \mathrm{~mL})$, the combined organic phase is washed with brine $(15 \mathrm{~mL})$ and dried over $\mathrm{MgSO}_{4}$. The solvent and traces of trifluoroacetic acid
Table 4. Results for the synthesis of fluorinated thioureas 30-33. 
are removed by distillation. The residue is purified by silica gel chromatography (pentane/diethyl ether, 1:1) affording the fluorinated urea as colorless solid or oils.

\subsubsection{Exemplarily Data for Fluorinated Ureas}

$N$-(2-Fluorohexadec-2-en-1-yl)- $N^{\prime}, N^{\prime}$ pentamethylene urea (10): Yield: $62 \mathrm{mg}$ (79\%), yellow oil.

${ }^{1} \mathrm{H}$ NMR $\left(300 \mathrm{MHz}, \mathrm{CDCl}_{3}\right): \delta=0.87$ $\left(\mathrm{t}, J=6.7 \mathrm{~Hz}, 3 \mathrm{H}, 10-\mathrm{CH}_{3}\right), 1.25-1.39(\mathrm{~m}$, $\left.10 \mathrm{H}, 5-\mathrm{CH}_{2}-9-\mathrm{CH}_{2}\right), 1.52-1.63(\mathrm{~m}, 6 \mathrm{H}$, $\left.13-\mathrm{CH}_{2}-15 \mathrm{CH}_{2}\right), 2.03\left(\mathrm{~m}, 2 \mathrm{H}, 4-\mathrm{CH}_{2}\right)$, $3.33\left(\mathrm{~m}, 4 \mathrm{H}, 16 / 12-\mathrm{CH}_{2}\right), 3.92$ (dd, $\left.J=5.4, J=16.0 \mathrm{~Hz}, 2 \mathrm{H}, 1-\mathrm{CH}_{2}\right), 4.74$ (br s, $1 \mathrm{H}, N \mathrm{H}) 4.76(\mathrm{dt}, J=7.5 \mathrm{~Hz}, J=$ $37.4 \mathrm{~Hz}, 1 \mathrm{H}, 3-\mathrm{CH}) .{ }^{13} \mathrm{C}$ NMR (101 MHz, $\left.\mathrm{CDCl}_{3}\right): \delta=14.1(\mathrm{C}-10), 22.6$ (C-9), 23.4 $(\mathrm{d}, J=4.2 \mathrm{~Hz}, \mathrm{C}-4), 24.6$ (C-14), 25.6 (C13/15), 28.3, 28.7 (C-6 and C-7), 29.029.2 (C-5 - C-7), 31.8 (C-8), 41.6 (d, $J=$ $31.1 \mathrm{~Hz}, \mathrm{C}-1), 44.9$ (C-12/16), 107.5 (d, J $=14.4 \mathrm{~Hz}, \mathrm{C}-3), 156.0(\mathrm{~d}, J=252.8 \mathrm{~Hz}$, C-2), 157.1 (C-11). ${ }^{19} \mathrm{~F}$ NMR (282 MHz, $\left.\mathrm{CDCl}_{3}\right): \delta=-118.2(\mathrm{dt}, J=16.1 \mathrm{~Hz}, J=$ $37.4 \mathrm{~Hz}$ ). HRMS (ESI): $\mathrm{m} / \mathrm{z}$ calcd for $[\mathrm{M}+$ $\mathrm{Na}]^{+}:$307.2156; found: 307.2156.

$N$-(2-Fluorohexadec-2-en-1-yl)- $N^{\prime}$ phenylurea (11): Yield: $22 \mathrm{mg}(30 \%)$. Mp $107^{\circ} \mathrm{C}$

${ }^{1} \mathrm{H}$ NMR (300 MHz, methanol-d $\mathrm{d}_{4}$ ): $\delta=0.88\left(\mathrm{t}, J=6.7 \mathrm{~Hz}, 3 \mathrm{H}, 16-\mathrm{CH}_{3}\right)$, 1.24-1.37 (m, $\left.22 \mathrm{H}, 5-\mathrm{CH}_{2}-15-\mathrm{CH}_{2}\right)$, $2.06\left(\mathrm{~m}, 2 \mathrm{H}, 4-\mathrm{CH}_{2}\right), 3.88(\mathrm{dd}, J=5.5, J$ $\left.=16.2 \mathrm{~Hz}, 2 \mathrm{H}, 1-\mathrm{CH}_{2}\right), 4.78(\mathrm{dt}, J=7.5$ $\mathrm{Hz}, J=37.5 \mathrm{~Hz}, 1 \mathrm{H}, 3-\mathrm{CH}), 6.99$ (m, 1 H, 21-CH), 7.25 (m, 2 H, 20/22-CH), 7.34 (m, $2 \mathrm{H}, 19 / 23-\mathrm{CH}) .{ }^{13} \mathrm{C}$ NMR $(101 \mathrm{MHz}$, methanol-d $)_{4}$ : $\delta=17.8(\mathrm{C}-16), 26.5(\mathrm{C}-15)$, $27.2(\mathrm{~d}, J=4.4 \mathrm{~Hz}, \mathrm{C}-4), 33.0-33.5$ (C-5 - C-14), 35.7 (C-5), 44.2 (d, $J=32.6 \mathrm{~Hz}$, C-1), 111.1 (d, $J=14.3 \mathrm{~Hz}, \mathrm{C}-3), 126.4$ (C21), 122 (C-19/23), 132.7 (C-20/22), 143.1 (C-18), 159.6 (d, $J=253.1 \mathrm{~Hz}, \mathrm{C}-2), 159.9$ (C-17). ${ }^{19} \mathrm{~F}$ NMR (282 MHz, methanol-d $)$ : $\delta=-118.6(\mathrm{dt}, J=16.3 \mathrm{~Hz}, J=37.7 \mathrm{~Hz})$. HRMS (ESI): $m / z$ calcd for $[\mathrm{M}+\mathrm{Na}]^{+}$: 399.2782; found: 399.2776 .

\subsection{General Procedures for the Synthesis of Isothiocyanates} 4.2.1 Synthesis of the Methanesulfonate 17

The fluorinated allyl alcohol 1 (348 mg, $2.00 \mathrm{mmol}, 1.0$ equiv) was dissolved in dichloromethane $(5 \mathrm{~mL})$ and cooled to $0{ }^{\circ} \mathrm{C}$. Triethylamine $(0.55 \mathrm{~mL}, 3.60 \mathrm{mmol}, 1.8$ equiv) and methanesulfonylchloride ( 0.23 $\mathrm{mL}, 3.00 \mathrm{mmol}, 1.5$ equiv) was added. The mixture was warmed to room temperature and stirred for $30 \mathrm{~min}$. Water $(5 \mathrm{~mL})$ was added and the phases were separated. The aqueous phase was extracted three times with dichloromethane $(10 \mathrm{~mL})$ and the combined organic phases were dried over $\mathrm{MgSO}_{4}$. After column filtration on silica gel the resulting methanesulfonate $\mathbf{1 7}$ was obtained. Yield: $291 \mathrm{mg}$ (1.11 mmol, $56 \%$ ), yellow oil.

${ }^{1} \mathrm{H}$ NMR $\left(300 \mathrm{MHz}, \mathrm{CDCl}_{3}\right): \delta=0.87$ $\left(\mathrm{t}, J=6.7 \mathrm{~Hz}, 3 \mathrm{H}, 10-\mathrm{CH}_{3}\right), 1.29(\mathrm{~m}$, $\left.10 \mathrm{H}, 5-\mathrm{CH}_{2}-9-\mathrm{CH}_{2}\right), 1.78-1.91(\mathrm{~m}, 2 \mathrm{H}$, 4- $\mathrm{CH}_{2}$ ), 3.04 (s, $\left.3 \mathrm{H}, 11-\mathrm{CH}_{3}\right), 4.74$ (dd, $\left.J=3.5 \mathrm{~Hz}, J=47.5 \mathrm{~Hz}, 1 \mathrm{H}, 1-\mathrm{CH}_{\mathrm{A}}\right), 4.90$ $\left(\mathrm{dd}, J=3.5 \mathrm{~Hz}, J=16.0 \mathrm{~Hz}, 1 \mathrm{H}, 1-\mathrm{CH}_{\mathrm{B}}\right.$ ), $4.90(\mathrm{dt}, J=3.5 \mathrm{~Hz}, J=15.9 \mathrm{~Hz}, 1 \mathrm{\textrm {H }}$, 3-CH). ${ }^{13} \mathrm{C}$ NMR (75 MHz, $\left.\mathrm{CDCl}_{3}\right): \delta=$ 14.1 (C-10), 22.7 (C-9), 24.9 (C-5), 29.031.9 (C-4 - C-9), 39.0 (C-11), 79.4 (d, J = $29.6 \mathrm{~Hz}, \mathrm{C}-3), 95.3$ (d, $J=17.1 \mathrm{~Hz}, \mathrm{C}-1)$, $160.8(\mathrm{~d}, J=261.8 \mathrm{~Hz}, \mathrm{C}-2) .{ }^{19} \mathrm{~F}$ NMR $\left(282 \mathrm{MHz}, \mathrm{CDCl}_{3}\right): \delta=-112.7$ (ddd, $J=$ $16.1 \mathrm{~Hz}, J=18.3 \mathrm{~Hz}, J=47.4 \mathrm{~Hz})$. HRMS (ESI): $m / z$ calcd for $[\mathrm{M}+\mathrm{Na}]^{+}: 252.1195$; found: 252.1197 .

\subsubsection{Synthesis of the \\ Toluenesulfonate}

The fluorinated allyl alcohol 1 (400 $\mathrm{mg}, 1.55 \mathrm{mmol}, 1.0$ equiv) was dissolved in dichloromethane $(15 \mathrm{~mL})$ and cooled to $0{ }^{\circ} \mathrm{C}$. Triethylamine $(0.64 \mathrm{~mL}, 4.65 \mathrm{mmol}$, 1.8 equiv) and dimethylaminopyridine (DMAP) (19 mg, $0.15 \mathrm{mmol}, 0.1$ equiv) was added. $p$-Toluenesulfonyl chloride (590 mg, $2.00 \mathrm{mmol}, 1.5$ equiv) was added and the mixture was stirred at room temperature for $48 \mathrm{~h}$ (TLC control). Water (20 $\mathrm{mL}$ ) was added and the phases were separated. The organic phase was washed with $2 \mathrm{~N} \mathrm{HCl}(20 \mathrm{~mL})$ and brine $(20 \mathrm{~mL})$. The combined organic phases were dried over $\mathrm{MgSO}_{4}$. After column chromatography on silica gel the resulting toluenesulfonate was obtained as yellow oil. Yield: $360 \mathrm{mg}$ (0.87 mmol, 56\%).

${ }^{1} \mathrm{H}$ NMR $\left(300 \mathrm{MHz}, \mathrm{CDCl}_{3}\right): \delta=0.86$ $\left(\mathrm{t}, J=6.6 \mathrm{~Hz}, 3 \mathrm{H}, 16-\mathrm{CH}_{3}\right), 1.25(\mathrm{~m}$, $\left.22 \mathrm{H}, 5-\mathrm{CH}_{2}-15-\mathrm{CH}_{2}\right), 1.77(\mathrm{~m}, 2 \mathrm{H}$, $\left.4-\mathrm{CH}_{2}\right), 2.43$ (s, $\left.3 \mathrm{H}, 23-\mathrm{CH}_{3}\right), 4.47$ (dd, $\left.J_{\mathrm{H}}=3.4 \mathrm{~Hz}, J=47.4 \mathrm{~Hz}, 1 \mathrm{H}, 1-\mathrm{CH}_{\mathrm{A}}\right)$, $4.63(\mathrm{dd}, J=3.5 \mathrm{~Hz}, J=16.1 \mathrm{~Hz}, 1 \mathrm{H}, 1-$ $\left.\mathrm{CH}_{\mathrm{B}}\right), 4.87(\mathrm{dt}, J=6.9 \mathrm{~Hz}, J=17.0 \mathrm{~Hz}$, $1 \mathrm{H}, 3-\mathrm{CH}), 7.31(\mathrm{~d}, J=8.0 \mathrm{~Hz}, 2 \mathrm{H}, 19-$ $\mathrm{CH}), 7.77(\mathrm{~d}, J=8.4 \mathrm{~Hz}, 2 \mathrm{H}, 18-\mathrm{CH}) .{ }^{13} \mathrm{C}$ NMR (75 MHz, $\mathrm{CDCl}_{3}$ ): $\delta=14.2(\mathrm{C}-16)$, 21.7 (C-23), 22.8 (C-15), 24.7 (C-5), 29.1 (C-4), 29.4-29.8 (C-7 - C-13), 31.9 (C-6), 32.0 (C-14), 79.2 (d, $J=31.3 \mathrm{~Hz}, \mathrm{C}-3), 94.5$ (dd, $J=17.0 \mathrm{~Hz}, \mathrm{C}-1), 127.9$ (d, C-18/22), 129.8 (d, C-19/21), 134.2 (s, C-20), 144.9 (s, C-17), 160.8 (d, J = 261.4 Hz, C-2). ${ }^{19} \mathrm{~F}$ $\operatorname{NMR}\left(282 \mathrm{MHz}, \mathrm{CDCl}_{3}\right): \delta=-112.7$ (ddd, $J=16.6 \mathrm{~Hz}, J=16.6 \mathrm{~Hz}, J=47.4 \mathrm{~Hz})$. HRMS (ESI): $\mathrm{m} / \mathrm{z}$ calcd for $[\mathrm{M}+\mathrm{Na}]^{+}$: 435.2339; found: 435.2339 .

\subsubsection{Rearrangement of Thiocyanates to Isothiocyanates}

In a sealed tube under argon atmosphere the methanesulfonyl derivative (1 equiv) is dissolved in dry THF (3 mL) and potassium thiocyanate is added (188 $\mathrm{mg}, 1.9 \mathrm{mmol}, 1.5$ equiv). The mixture is heated to $60{ }^{\circ} \mathrm{C}$ over $26 \mathrm{~h}$. Water $(10 \mathrm{~mL})$ and diethyl ether $(10 \mathrm{~mL})$ is added and the phases are separated. The aqueous phase is extracted four more times with diethyl ether. The combined organic phases are dried over $\mathrm{MgSO}_{4}$ and the solvent is evaporated in vacuo. After column filtration on silica gel the resulting isothiocyanates are obtained as yellow oils.

trans-2-Fluoro-1-isothiocyanatohexadec-2-ene (18):

${ }^{1} \mathrm{H}$ NMR (300 $\left.\mathrm{MHz}, \mathrm{CDCl}_{3}\right): \delta=$ 0.87 (t, $\left.J=6.7 \mathrm{~Hz}, 1 \mathrm{H}, 16-\mathrm{CH}_{3}\right), 1.26$ (m, $\left.22 \mathrm{H}, 5-\mathrm{CH}_{2}-15-\mathrm{CH}_{2}\right), 2.08-2.15(\mathrm{~m}$, $\left.2 \mathrm{H}, 4-\mathrm{CH}_{2}\right), 4.30(\mathrm{~d}, J=13.7 \mathrm{~Hz}, 1 \mathrm{H}$, $\left.2-\mathrm{CH}_{2}\right), 4.90(\mathrm{dt}, J=7.6, J=35.8 \mathrm{~Hz}, 1 \mathrm{H}$, $3-\mathrm{CH}) \cdot{ }^{13} \mathrm{C}$ NMR $\left(75 \mathrm{MHz}, \mathrm{CDCl}_{3}\right): \delta 14.1$ (C-16), 22.6 (C-15), 22.3 (d, $J=3.6 \mathrm{~Hz}$, C-5), 28.9, 29.0, 29.3, 29.5 29.6 (C-6 C-14), 31.9 (C-4), 45.7 (d, $J=35.0 \mathrm{~Hz}$, C-1), 110.2 (d, J=13.2 Hz, C-3), 151.3 (d, $J=254.6 \mathrm{~Hz}, \mathrm{C}-2) .{ }^{19} \mathrm{~F}$ NMR $(282 \mathrm{MHz}$, $\left.\mathrm{CDCl}_{3}\right): \delta=-118.6(\mathrm{dt}, J=13.6 \mathrm{~Hz}, J=$ $35.6 \mathrm{~Hz}$ ). HRMS (ESI): $\mathrm{m} / \mathrm{z}$ calcd for $[\mathrm{M}+$ $\mathrm{Na}]^{+}:$322.1975; found: 322.1978 .

trans-2-Fluoro-1-isothiocyanatodec2-ene (19):

${ }^{1} \mathrm{H}$ NMR (400 MHz, $\left.\mathrm{CDCl}_{3}\right): \delta=0.88$ $\left(\mathrm{t}, J=6.7 \mathrm{~Hz}, 3 \mathrm{H}, 10-\mathrm{CH}_{3}\right), 1.28-1.39$ (m, $\left.10 \mathrm{H}, 5-\mathrm{CH}_{2}-9-\mathrm{CH}_{2}\right), 2.09-2.14(\mathrm{~m}$, $\left.2 \mathrm{H}, 4-\mathrm{CH}_{2}\right), 4.13(\mathrm{~d}, J=13.4 \mathrm{~Hz}, 2 \mathrm{H}$, $\left.1-\mathrm{CH}_{2}\right), 4.89$ (dt, $J=7.6 \mathrm{~Hz}, J=35.6 \mathrm{~Hz}$, $1 \mathrm{H}, 3-\mathrm{CH}) .{ }^{13} \mathrm{C}$ NMR $\left(101 \mathrm{MHz}, \mathrm{CDCl}_{3}\right)$ : $\delta=14.1(\mathrm{C}-10), 22.6$, (C-9), $25.0(\mathrm{C}-5)$, 28.9, 30.7, 31.8 (C-6 - C-8), 45.8 (d, $J=3$ 5.3), $110.2(\mathrm{~d}, J=13.2 \mathrm{~Hz}, \mathrm{C}-1), 135.4(\mathrm{~s}$, $\mathrm{C}-11), 151.4(\mathrm{~d}, J=254.4 \mathrm{~Hz}, \mathrm{C}-2) .{ }^{19} \mathrm{~F}$ NMR (282 MHz, $\mathrm{CDCl}_{3}$ ): $\delta=-118.4(\mathrm{dt}$, $J=13.4 \mathrm{~Hz}, J=35.6 \mathrm{~Hz}$ ). HRMS (ESI): $\mathrm{m} / \mathrm{z}$ calcd for $[\mathrm{M}+\mathrm{Na}]^{+}: 238.1036$; found: 238.1032 .

cis/trans-2-Fluoro-1-thiocyanatooctadec-2-ene (28):

In a sealed tube the 1:2 cis/trans-mixture of mesylate 27 (38 mg, $0.1 \mathrm{mmol}$ ) was dissolved in $2 \mathrm{~mL} \mathrm{MeCN}$ and KSCN (11 $\mathrm{mg}, 0.15 \mathrm{mmol}, 1.5$ equiv). The mixture was heated at $60{ }^{\circ} \mathrm{C}$ for $3 \mathrm{~h}$. Water $(5 \mathrm{~mL})$ and diethyl ether $(5 \mathrm{~mL})$ was added and the phases were separated. The aqueous phase was extracted four more times with diethyl ether. The combined organic phases were dried over $\mathrm{MgSO}_{4}$ and the solvent was evaporated in vacuo and the residue was used without further purification for the rearrangement. The mixture contained already $34 \%$ of the rearrangement product 29.

$\left.{ }^{19} \mathrm{~F} \mathrm{NMR} \mathrm{(282} \mathrm{MHz}, \mathrm{CDCl}_{3}\right): \delta=$ -116.1 (m) (trans), -109.1 (m) (cis), cis/ trans $1: 2 ; \delta=-108.9$ (29).

2-Fluoro-3-isothiocyanatoocatadec-1ene (29):

The crude reaction mixture of $\mathbf{2 8}$ was dissolved in toluene ( $4 \mathrm{~mL})$ and heated under reflux for 4 h. Following work up pro- 
cedure is similar to other rearrangements. The thiocyanate was obtained as yellow oil. Yield: $20 \mathrm{mg}$ (0.06 mmol, 61\%).

${ }^{1} \mathrm{H}$ NMR (300 MHz, $\left.\mathrm{CDCl}_{3}\right): \delta=0.88$ $\left(\mathrm{t}, J=6.7 \mathrm{~Hz}, 3 \mathrm{H}, 18-\mathrm{CH}_{3}\right), 1.26(\mathrm{~m}, 26$ $\left.\mathrm{H}, 5-\mathrm{CH}_{2}-17-\mathrm{CH}_{2}\right), 1.72-1.80(\mathrm{~m}, 2 \mathrm{H}$, $\left.4-\mathrm{CH}_{2}\right), 4.14(\mathrm{dt}, J=6.7 \mathrm{~Hz}, J=11.7 \mathrm{~Hz}$, $1 \mathrm{H}, 3-\mathrm{CH}), 4.55(\mathrm{dd}, J=3.8 \mathrm{~Hz}, J=47.6$ $\left.\mathrm{Hz}, 1 \mathrm{H}, 1-\mathrm{CH}_{\mathrm{A}}\right), 4.71(\mathrm{dd}, J=3.7 \mathrm{~Hz}, J=$ $\left.16.5 \mathrm{~Hz}, 1 \mathrm{H}, 1-\mathrm{CH}_{\mathrm{B}}\right) .{ }^{13} \mathrm{C} \mathrm{NMR}(75 \mathrm{MHz}$, $\left.\mathrm{CDCl}_{3}\right): \delta=13.1(\mathrm{C}-18), 21.7(\mathrm{C}-17), 24.5$ (C-5), 29.7, 29.8, 29.9, 30.0, 30.3, 32.3 (C4 and C-6 - C-16), 56.9 (dd, $J=31.1 \mathrm{~Hz}$, C-3), 91.1 (dd, $J=17.8 \mathrm{~Hz}, \mathrm{C}-1$ ), 131.7 (C-19), 160.4 (dd, $J=260.9 \mathrm{~Hz}, \mathrm{C}-2) .{ }^{19} \mathrm{~F}$ $\mathrm{NMR}\left(282 \mathrm{MHz}, \mathrm{CDCl}_{3}\right): \delta=-108.9$ (ddd, $J=11.6, J=16.5, J=47.6 \mathrm{~Hz})$. HRMS (ESI): $\mathrm{m} / \mathrm{z}$ calcd for $[\mathrm{M}+\mathrm{Na}]^{+}: 350.2288$; found: 350.2288 .

\subsection{General Procedure for the Synthesis of Fluorinated Thioureas}

The corresponding isothiocyanate $(0.2 \mathrm{mmol})$ is microwave irradiated to $100{ }^{\circ} \mathrm{C}$ with the amine $(0.1 \mathrm{~mL})$ for $1 \mathrm{~h}$. Dichloromethane $(5 \mathrm{~mL})$ and $2 \mathrm{~N} \mathrm{HCl}(5$ $\mathrm{mL}$ ) is added and the phases are separated. The organic phase is washed with brine and dried over $\mathrm{MgSO}_{4}$. The resulting residue is purified by silica gel chromatography (cyclohexane/ethyl acetate, 10:1).

$N$-(2-Fluorohexadec-2-en-1-yl)-N'phenylthiourea (31):

${ }^{1} \mathrm{H}$ NMR (300 MHz, $\left.\mathrm{CDCl}_{3}\right): \delta=0.87$ $\left(\mathrm{t}, J=6.7 \mathrm{~Hz}, 1 \mathrm{H}, 16-\mathrm{CH}_{3}\right), 1.25-1.36$ (m, $\left.22 \mathrm{H}, 5-\mathrm{CH}_{2}-15-\mathrm{CH}_{2}\right), 2.02-2.10(\mathrm{~m}$, $\left.2 \mathrm{H}, 4-\mathrm{CH}_{2}\right), 4.37$ (dd, $J=5.5, J=16.4 \mathrm{~Hz}$, $\left.1 \mathrm{H}, 2-\mathrm{CH}_{2}\right), 4.84(\mathrm{dt}, J=7.5, J=37.3 \mathrm{~Hz}$, $1 \mathrm{H}, 3-\mathrm{CH}), 6.19$ (bs, C-1-NH), 7.21-7.24 (m, $2 \mathrm{H}, 19 / 23-\mathrm{CH}), 7.30-7.34(\mathrm{~m}, 1 \mathrm{H}$, 21-CH), 7.42-7.48 (m, 2 H, 20/22-CH), 8.00 (bs, $1 \mathrm{H}, \mathrm{NH}) .{ }^{13} \mathrm{C}$ NMR $(75 \mathrm{MHz}$, $\left.\mathrm{CDCl}_{3}\right): \delta=14.1(\mathrm{C}-16), 22.7(\mathrm{C}-15), 23.5$ $\left(\mathrm{d}, J_{\mathrm{C}}=4.0, \mathrm{C}-4\right), 29.0-34.7$ (C-5 - C-14), $46.2(\mathrm{~d}, J=30.0, \mathrm{C}-1), 109.6(\mathrm{~d}, J=13.8$ $\mathrm{Hz}, \mathrm{C}-1), 125.2$ (C-19/23), 127.5 (C-15), 130.3 (C-20/22), 135.8 (C-118), 153.7 (d, $J=252.8 \mathrm{~Hz}, \mathrm{C}-2), 180.8$ (C-17). ${ }^{19} \mathrm{~F}$ NMR $\left(282 \mathrm{MHz}, \mathrm{CDCl}_{3}\right): \delta=-118.1(\mathrm{dt}, J=16.5$ $\mathrm{Hz}, J=37.4 \mathrm{~Hz}$ ). HRMS (ESI): $m / z$ calcd for $[\mathrm{M}+\mathrm{Na}]^{+}:$415.2554; found: 415.1554 .

$N-\left(2\right.$-Fluorodec-2-en-1-yl)- $N^{\prime}, N^{\prime}$ pentamethylene-thiourea (32):

${ }^{1} \mathrm{H}$ NMR (400 MHz, $\left.\mathrm{CDCl}_{3}\right): \delta=0.88$ (t, $\left.J=6.7 \mathrm{~Hz}, 3 \mathrm{H}, 10-\mathrm{CH}_{3}\right), 1.27-1.37$ (m, $\left.10 \mathrm{H}, 5-\mathrm{CH}_{2}-9-\mathrm{CH}_{2}\right), 1.61-1.68$ (m, $\left.6 \mathrm{H}, 13 / 14 / 15-\mathrm{CH}_{2}\right), 2.05-2.11(\mathrm{~m}, 2 \mathrm{H}$, $\left.4-\mathrm{CH}_{2}\right), 3.79\left(\mathrm{~m}, 4 \mathrm{H}, 12 / 16-\mathrm{CH}_{2}\right), 4.41$ $\left(\mathrm{dd}, J=5.0 \mathrm{~Hz}, J=17.2 \mathrm{~Hz}, 2 \mathrm{H}, 1-\mathrm{CH}_{2}\right)$, $4.85(\mathrm{dt}, J=7.5 \mathrm{~Hz}, J=37.5 \mathrm{~Hz}, 1 \mathrm{H}$, 3-CH), 5.61 (bs, $1 \mathrm{H}, N \mathrm{H}) .{ }^{13} \mathrm{C}$ NMR (101 $\left.\mathrm{MHz}, \mathrm{CDCl}_{3}\right): \delta=14.1$ (C-10), $22.6(\mathrm{C}-9)$, $23.5(\mathrm{~d}, J=4.1, \mathrm{C}-4), 24.2$ (C-14), 25.4 (C-13/15), 28.9, 30.7, 31.8 (C-6 - C-8), $48.9(\mathrm{~d}, J=28.9, \mathrm{C}-1), 48.9(\mathrm{C} 12 / 16)$, $109.3(\mathrm{~d}, J=13.2 \mathrm{~Hz}, \mathrm{C}-1), 154.6(\mathrm{~d}, J$ $=252.9 \mathrm{~Hz}, \mathrm{C}-2), 181.1(\mathrm{C}-11) .{ }^{19} \mathrm{~F}$ NMR $\left(282 \mathrm{MHz}, \mathrm{CDCl}_{3}\right): \delta=-117.9(\mathrm{dt}, J=$ $17.2 \mathrm{~Hz},{ }^{3} J_{\mathrm{H}, \mathrm{F}}=37.2 \mathrm{~Hz}$ ). HRMS (ESI): $\mathrm{m} / \mathrm{z}$ calcd for $[\mathrm{M}+\mathrm{Na}]^{+}: 323.1928$; found: 323.1929 .

\section{Acknowledgements}

Financial support by the Deutsche Forschungsgemeinschaft (DFG, Project $\mathrm{Ha}$ 2145/12-1) is gratefully acknowledged.

Received: April 3, 2014

[1] a) R. G. Guy, 'Synthesis and preparative applications of thiocyanates', in: 'The chemistry of cyanates and their thio derivatives', Part 2, Ed. S. Patai, John Wiley \& Sons, Chichester, 1977, pp 819-886; b) L. Drobnica, P. Christian, J. Augustin, 'Synthesis and preparative applications of isocyanates', in: 'The chemistry of cyanates and their thio derivatives', Part 2 , Ed. S. Patai, John Wiley \& Sons, Chichester, 1977, pp 1003-1221; c) S. Braverman, M. Cherkinsky, M. L. Birsa, 'Science of Synthesis', Thieme, Stuttgart, 2005, pp 211-213.

[2] a) W. Walter, K. D. Bode, Angew. Chem. Int. Ed. 1967, 6, 281; Angew. Chem. 1967, 79, 285; b) C. Richter, K. Klatt, A. Feuerer, K. Schulze, $J$ Prakt. Chem. 1992, 334, 60; c) For an overview see: Y.-Q. Wu, in: 'Science of Synthesis', Vol. 18, Ed. J. G. Knight, Thieme, Stuttgart, 2005, pp 188-310.

[3] a) P. R. Schreiner, Chem. Soc. Rev. 2003, 32, 289; b)A. G. Doyle, E. N. Jacobsen, Chem. Rev. 2007, 107, 5713 .

[4] a) O. Billeter, Ber. Dtsch. Chem. Ges. 1885, 8 , 462; b) G. Gerlich, Justus Liebigs Ann. Chem. 1885, 178, 337; c) O. Billeter, Helv. Chim. Acta 1925, 8, 337; d) H. J. Hansen, Chimia 1999, 53, 163; e) H. J. Hansen, Chimia 2000, 54, 105

[5] a) O. Mumm, M. Richter, Chem. Ber. 1940, 73, 843; b) P. A. S. Smith, D. W. Emerson, J. Am Chem. Soc. 1960, 82, 3076; c) A. Fava, Angew. Chem. 1965, 77, 271; d) E. H. M. Abd Elall, M. I. Al Ashmawy, J. M. Mellor, J. Chem. Soc., Perkin Trans. 1 1987, 2729; e) K. Schulze. G. Haufe, G. Köhler, Z. Chem. 1989, 29, 167; f) D. M. Emerson, R. L. Titus, J. Org. Chem. 1994, $59,5109$.

[6] a) M. Kotani, Y. Shigetomi, M. Imada, M. Oki, Heteroatom Chem. 1997, 8, 35; b) R. Koch, J. J. Finnerty, S. Murali, C. Wentrup, J. Org. Chem. 2012, 77, 1749.

[7] K. Banert, M. Hagedorn, A. Müller, Eur. J. Org. Chem. 2001, 1089

[8] a) K. A. Jensen, A. Holm, 'Syntheses and preparative applications of cyanates', in: 'The chemistry of cyanates and their thio derivatives ', Part 1, Ed. S. Patai, John Wiley \& Sons, Chichester, 1977, pp 569-618. b) D. E. Gilges, 'Kinetics and mechanism of reactions of cyanates and related compounds', in: 'The chemistry of cyanates and their thio derivatives', Part 1, Ed. S. Patai, John Wiley \& Sons, Chichester, 1977, pp 381-444.

[9] a) C. Christophersen, A. Holm, Acta Chem. Scand. 1970, 24, 1512; b) L. Overman, M. Kakimoto, J. Org. Chem. 1978, 43, 4563; c) Y. Ichikawa, K. Tsuboi, M. Isobe, J. Chem. Soc., Perkin Trans. 1 1994, 2791; d) K. Bahnert, S. Groth, Angew. Chem. Int. Ed. Engl. 1992, 31, 866.

[10] a) S. Braverman, M. Cherkinsky, M. L. Birsa, 'Science of Synthesis', Vol 18, Thieme, Stuttgart, 2005, pp 135-137; b) Y. Ichikawa, Synlett 2007, 2927.

[11] a) H. Ulrich, 'Reactions of alkyl and aryl isocyanates', in: 'The Chemistry and Technology of Isocyanates', Wiley, 1996; b) E. Delebecq. J. P. Pacault, B. Boutevin, F. Ganachaud, Chem. Rev. 2013, 113, 80; c) J. H. Saunders, R. J. Slocombe, Chem. Rev. 1948, 43, 203.

[12] a) H. Ho, A. Sato, T. Kobayashi, T. Taguchi, Chem. Commun. 1998, 2441. b) F. Tellier, M. Audouin, M. Baudry, R. Sauvetre, Eur. J. Org. Chem. 2000, 1933, and references cited therein.

[13] a) T. Taguchi, T. Morikawa, O. Kitagawa, T. Mishima, Y. Kobayashi, Chem. Pharm. Bull. 1985, 33, 5137; b) J. M. Percy, M. E. Prime, J. Org. Chem. 1998, 63, 8049, and references cited therein.

[14] J. M. Percy, M. E. Prime, J. Fluorine Chem. 1999, 100, 147, and references cited therein.

$[15]$ a) T. Allmendiger, C. Angst, H. Karfunkel, $J$. Fluorine Chem. 1995, 72, 247; b) M. Schlosser, D. Michel, S. L. Croft, Synthesis 1996, 591; c) S. J. Brown, S. Corr, J. M. Percy, Tetrahedron Lett. 2000, 41, 5269.

[16] a) F. Tranel, G. Haufe, J. Fluorine Chem. 2004, 125, 1593; b) F. Tranel, R. Fröhlich, G. Haufe, J. Fluorine Chem. 2005, 126, 557; c) U. Wittmann, F. Tranel, R. Fröhlich, G. Haufe, Synthesis 2005, 2085; d) M. Marhold, U. Wittmann, S. Grimme, T. Takahashi, G. Huafe, J. Fluorine Chem. 2007, 128, 1306; e) J. Walkowiak, M. Tomas-Szwaczyk, G. Haufe, H. Koroniak, J. Fluorine Chem. 2012, 143, 189; f) D. C. Ramb, G. Haufe, Synlett 2013, 24, 2229.

[17] a) G. Alvernhe, A. Laurent, G. Haufe, Synthesis 1987, 562; b) G. Haufe, G. Alvernhe, E. Laurent, T. Ernet, O. Goj, S. Kröger, A. Sattler, Org. Synth. 1999, 76, 159; c) T. Ernet, G. Haufe, Synthesis 1997, 953.

[18] I. Ichikawa, Synlett 1991, 238.

[19] P. Kočovský, Tetrahedron Lett. 1986, 72, 5521.

[20] a) R. Loos, S. Kobayashi, H. Mayr, J. Am. Chem. Soc. 2003, 125, 14126; b) H. Mayr, M. Breugst, R. Ofial, Angew. Chem. 2011, 123, 6598; Angew. Chem. Int. Ed. 2011, 50, 6470; c) A. Fava, A. Iliceto, S. Bresadola, J. Am. Chem. Soc. 1965, 87, 4791 .

[21] G. S. Nikolova, L. Zhang, X. Chen, L. Chi, G. Haufe, Colloids Surf. A 2008, 317, 414.

[22] J. G. Smith, S. E. Drozda, S. P. Petraglia, N. R. Quinn, E. M. Rice, B. S. Taylor, M. Viswanthan, J. Org. Chem. 1984, 49, 4112. 